\title{
EFEK DAMBI (DAUN JAMBU BIJI) (Psidium guajava Linn) TERHADAP PENYEMBUHAN LUKA PADA KULIT
}

\section{DAMBI (GUAVA LEAVES) (Psidium guajava linn) EFFECT ON WOUND SKIN HEALING}

\author{
Ulil Abshor, Sri Wahyu Basuki
}

Fakultas Kedokteran Universitas Muhammadiyah Surakarta

Korespondensi; dr. Sri Wahyu Basuki, M. Kes. Email: swb191@ums.ac.id

\begin{abstract}
ABSTRAK
Kandungan senyawa daun jambu biji (Psidium guajava Linn) yang dapat membantu penyembuhan luka adalah alkaloid, saponin, tanin dan flavanoid. Penelitian ini bertujuan mengetahui khasiat daun jambu biji sebagai obat alternatif untuk pengobatan luka. Jenis penelitian ini eksperimental laboratorium dengan metode pre test dan post test only control group design. Teknik pengambilan sampel menggunakan purposive sampling. Sampel sejumlah 24 ekor tikus dikelompokkan menjadi 4 kelompok, yaitu: kelompok kontrol negative, kontrol positif, kelompok ekstrak dengan pelarut air, dan kelompok ekstrak pelarut alkohol. Data dianalisis menggunakan uji Friedman dan diakhiri post hoc uji wilcoxon.Hasil penelitian menunjukkan bahwa pemberian ekstrak daun jambu biji dengan pelarut alkohol lebih cepat mengalami penyembuhan luka dibandingkan kelompok lainnya $(p<0,05)$. Terdapat hubungan antara Efek DAMBI (Daun Jambu Biji) terhadap penyembuhan luka pada kulit.
\end{abstract}

Kata kunci : Daun Jambu Biji, Luka, Flavanoid, Alkaloid, Kulit

\section{ABSTRACT}

The compotitions of guava leaves (Psidium guajava Linn) that help wound healing are alkaloids, saponins, tannins and flavonoids. The aim of this research is determine the efficacy of guava leaves as an alternative medicine for the treatment of wounds. This study is laboratory experimental research with pre-test research methods and post test only control group design. This study used 24 rats that were divided into 4 groups, negative control group, positive control group (povidone iodine group), extract with water solvent group, and extract alcohol solvent group. Data were analyzed using the Friedman test and ending with post hoc Wilcoxon test. The results showed that administration of guava leaf extract with alcohol solvent more rapid wound healing compared to others $(p<0.05)$. There is a relationship between the effects Dambi (guava leaves) on the skin wound healing.

Keywords : Guava Leaves, Wound, Flavonoids, Alkaloids, Skin

How To Cite: Abshor, U., \& Basuki, S. (2019). EFEK DAMBI (DAUN JAMBU BIJI) (Psidium guajava Linn) TERHADAP PENYEMBUHAN LUKA PADA KULIT. Biomedika, 11(2), $105-112$. doi:https://doi.org/10.23917/biomedika.v11i2.8546

DOI: https://doi.org/10.23917/biomedika.v11i2.8546 


\section{PENDAHULUAN}

Pengobatan luka secara tradisional sudah jarang ditemukan di era sekarang ini. Hal ini disebabkan karena luka umumnya diobati dengan obat kimiawi seperti povidone iodine yang menimbulkan banyak efek samping diantaranya iododerma (Aliagaoglu et al., 2013), luka bakar kimawi, hingga reaksi anafilaksis (Gray et al., 2013). Sementara alam selama ribuan tahun memiliki sumber ketersediaan obat tradisional, bahkan sebagian obat modern juga diisolasi dari sumber alami (Venkatachalam et al., 2012). Pengobatan tradisional terhadap luka merupakan salah satu pemanfaatan obat yang berasal dari alam dengan biaya yang lebih murah dan mudah didapatkan. Pengobatan luka secara alami dapat menggunakan daun-daunan dari tanaman yang mengandung senyawa metabolit sekunder yang berfungsi sebagai penyembuhan luka, salah satunya adalah menggunakan daun jambu biji. Kandungan senyawa metabolit sekunder yang terdapat dalam daun jambu biji yang dapat membantu penyembuhan luka, diantaranya: alkaloid, saponin, tanin, dan flavanoid (Kaneria and Chandra, 2011; Ndukwe et al., 2013)
Flavanoid yang terdapat pada daun jambu biji memiliki fungsi untuk menghambat pendarahan, dengan cara meningkatkan jumlah trombosit, sehingga saat terjadi pendarahan pada tubuh trombosit akan pecah dan menghasilkan enzim trombokinase atau tromboplastin yang selanjutnya akan bekerja sebagai enzim untuk mengaktifkan molekul fibrinogen membentuk monomer fibrin dibantu oleh ion $\mathrm{Ca}$ dan vitamin $\mathrm{K}$ yang terdapat pada plasma darah (Widjajakusumah, 2002). Saponin pada daun jambu biji memiliki fungsi sebagai perangsang pembentukan kolagen, yang merupakan protein utama pada jaringan ikat dan tulang. Kolagen memberikan kekuatan dan daya tahan kulit sehingga membantu dalam proses penyembuhan luka (Suratman et al., 1996). Alkaloid yang terdapat pada daun jambu biji berfungsi melawan infeksi mikrobia (Carey, 2006). Mekanisme kerjanya adalah dengan cara mengganggu komponen penyusun peptidoglikan pada sel bakteri sehingga lapisan dinding sel tidak terbentuk secara utuh sehingga menyebabkan kematian sel tersebut (Robinson, 1995). Berdasarkan kemampuan daun jambu biji tersebut dilakukan penelitian terhadap penyembuhan luka dan diharapkan dapat menggantikan obat kimiawi. 
Penelitian Aaron et al. (2016) menunjukkan bahwa daun dewa yang di aplikasikan pada luka insisi di punggung kanan dan kiri kelinci sepanjang $4 \mathrm{~cm}$ dan kedalaman 2 mm, memiliki efek antiseptik dan mempercepat penyembuhan luka melalui kandungan flavanoid,saponin dan tanin. Namun, daun dewa merupakan bahan yang sulit di cari sehingga dalam proses pembuatanya akan mengalami kendala, disamping itu penelitian sebelumnya hanya mengamati lama hari penutupan luka secara makroskopis.

Berdasarkan latar belakang tersebut, peneliti mencoba mengeksplorasi kekayaan alam yang relatif lebih mudah didapat dan di teliti secara mikroskopis untuk mengetahui pengaruh ekstrak daun jambu biji terhadap penyembuhan luka. Sehingga peneliti mengambil judul Efek Daun Jambu Biji (Psidium guajava Linn) terhadap Penyembuhan Luka pada kulit.

\section{METODE}

Penelitian ini termasuk penelitian eksperimental laboratorium dengan nomor etical clearance 0024/A.6-III/FK-BS/IV/2018 yang diterbitkan oleh Komite Etik Penelitian UMS. Metode penelitian yang digunakan adalah pre test \& post test only control group design. Pengambilan daun jambu biji dilakukan bulan Mei 2018 di kebun jambu biji Desa Ujung pasir, Kecamatan Wedung, Kabupaten Demak. Determinasi tanaman dilakukan di Laboratorium Biologi FKIP Universitas Muhammadiyah Surakarta pada bulan yang sama. Kemudian ekstraksi dilakukan di Laboratorium Farmasi Fakultas Farmasi Universitas Muhammadiyah Surakarta, dan pengamatan hitung jenis leukosit, perlakuan hewan dilakukan di Laboratorium Farmakologi, dan Laboratorium Patologi Klinik Fakultas Kedokteran Universitas Muhammadiyah Surakarta pada bulan Juli - Agustus 2018.Populasi aktual dalam penelitian ini adalah tikus jantan (Rattus novergicus) galur wistar berusia 2-3 bulan dengan berat badan 200-300 gram.

Teknik pengambilan sampel yang dipakai adalah purposive sampling, dimana pemilihan subjek sampel dipilih berdasarkan kriteria yang ditentukan oleh peneliti. Sampel berasal dari 24 ekor tikus yang telah dikelompokkan menjadi 4 kelompok, dan masing-masing kelompok terdapat 6 ekor tikus, yaitu: kelompok kontrol negatif, kontrol positif, ekstrak dengan pelarut air, dan ekstrak dengan 
pelarut alkohol. Hitung netrofil dan limfosit.

menggunakan preparat apus diamati dibawah mikroskop perbesaran 1000 kali.

\section{HASIL DAN PEMBAHASAN}

Penyembuhan luka diamati setiap hari, sehingga diperoleh lama penyembuhan luka pada masing-masing kelompok (tabel 1).

\begin{tabular}{|c|c|c|c|c|}
\hline & & & & \\
\hline $\begin{array}{l}\text { Pengamat } \\
\text { an }\end{array}$ & $\begin{array}{c}\text { Kontr } \\
\text { ol } \\
\text { Negati } \\
\text { f }\end{array}$ & $\begin{array}{l}\text { Kontr } \\
\text { ol } \\
\text { Positif }\end{array}$ & $\begin{array}{c}\text { Ekstr } \\
\text { ak } \\
\text { Denga } \\
\text { n } \\
\text { Pelaru } \\
\text { t Air }\end{array}$ & $\begin{array}{c}\text { Ekstr } \\
\text { ak } \\
\text { Denga } \\
\text { n } \\
\text { Pelaru } \\
\text { t } \\
\text { Alkoh } \\
\text { ol }\end{array}$ \\
\hline $\begin{array}{l}\text { Lama } \\
\text { penyembu } \\
\text { han (hari) }\end{array}$ & 13,84 & 12,50 & 12,34 & 10,34 \\
\hline
\end{tabular}

Tabel 1 diatas dapat diketahui bahwa lama penyembuhan dalam hari pada luka. Penyembuhan luka paling cepat dialami oleh ekstrak pelarut alkohol yaitu dalam 10,34 hari. Penyembuhan luka sedang dialami oleh ekstrak pelarut air dan kontrol positif, Sedangkan penyembuhan luka paling lambat dialami oleh kontrol negatif yaitu dalam 13,84 hari.

Uji Friedman dilakukan untuk mengetahui adakah hubungan antara ekstrak daun jambu biji baik pelarut air maupun alkohol terhadap penyembuhan luka. Uji Friedman dipilih karena memenuhi syarat yaitu hasil distribusi tidak normal lebih dari dua kelompok berpasangan. Dari hasil uji Friedman didapatkan nilai lama penyembuhan luka, netrofil dan limfosit $(\mathrm{p}<0,05)$. Oleh karena itu, kesimpulan yang didapatkan adalah setidaknya terdapat perbedaan antara jumlah nilai lama penyembuhan luka, netrofil dan limfosit terhadap kelompok pretest, postest 1, postest 2, dan postest 3. Berikut hasil uji Friedman.

Tabel 2 Hasil Uji Friedman Terhadap Rerata Lama Penyembuan Luka, Jumlah Netrofil, Dan Limfosit

\begin{tabular}{|c|c|c|}
\hline $\begin{array}{c}\text { Lama } \\
\text { Penyembuhan Luka }\end{array}$ & Rerata & $p$ \\
\hline Pretest & 3,67 & ,002 \\
\hline Postest 1 & 2,67 & \\
\hline Postest 2 & 2,67 & \\
\hline Postest 3 & 1,00 & \\
\hline \multicolumn{3}{|l|}{ Netrofil } \\
\hline Pretest & 1,08 & ,000 \\
\hline Postest 1 & 3,38 & \\
\hline Postest 2 & 3,08 & \\
\hline Postest 3 & 2,46 & \\
\hline \multicolumn{3}{|l|}{ Limfosit } \\
\hline Pretest & 2,29 & 002 \\
\hline Postest 1 & 3,17 & \\
\hline Postest 2 & 2,75 & \\
\hline Postest 3 & 1,79 & \\
\hline
\end{tabular}

Tabel 2 diatas menunjukkan $(\mathrm{p}<0,05)$, maka dapat disimpulkan bahwa terdapat perbedaan yang signifikan rerata lama penyembuan luka, jumlah netrofil jumlah limfosit di antara minimal dua kelompok perlakuan. Uji Wilcoxon merupakan uji post Hoc dari Friedman, yang dilakukan untuk mengetahui letak perbedaan jumlah lama penyembuhan luka, netrofil dan limfosit antara 
2 kelompok perlakuan. Hasil uji Wilcoxon terhadap lama penyembuhan lukamenunjukkan perbandingan yang memiliki hasil berbeda signifikan $(p<0,05)$ pada kontrol negatif dengan kontrol positif, kontrol negatif dengan ekstrak pelarut air, dan kontrol negatif dengan ekstrak pelarut alkohol, kontrol positif dengan ekstrak pelarut alkohol, dan ekstrak pelarut air dengan ekstrak pelarut alkohol. Sedangkan perbandingan yang memiliki hasil tidak berbeda signifikan pada kontrol positif dengan ekstrak pelarut air.

Hasil uji Wilcoxon terhadap netrofil menunjukkan hasil berbeda signifikan $(\mathrm{p}<0,05)$ pada kontrol negatif dengan kontrol positif, kontrol negatif dengan ekstrak pelarut air, dan kontrol negatif dengan ekstrak pelarut alkohol. Sedangkan perbandingan yang memiliki hasil tidak berbeda signifikan pada kontrol positif dengan ekstrak pelarut air, kontrol positif dengan ekstrak pelarut alkohol, dan ekstrak pelarut air dengan ekstrak pelarut alkohol. Hasil uji Wilcoxon terhadap limfosit menunjukkan hasil berbeda signifikan $(\mathrm{p}<0,05)$ pada kontrol negatif dengan kontrol positif, kontrol negatif dengan ekstrak pelarut air, kontrol negatif dengan ekstrak pelarut alkohol. Sedangkan perbandingan yang memiliki hasil tidak berbeda signifikan pada kontrol positif dengan ekstrak pelarut air, kontrol positif dengan ekstrak pelarut alkohol, dan ektrak pelarut air dengan ekstrak pelarut alkohol.

Hasil pengamatan menunjukkan bahwa lama penyembuhan terhadap jenis pengobatan terhadap daun jambu biji baik dengan pelarut air maupun alkohol menunjukkan penyembuhan lebih cepat ekstrak dengan pelarut alkohol dibandingkan ekstrak dengan pelarut air, kontrol positif dan kontrol negatif. Hal ini disebabkan adanya kandungan pada daun jambu biji yang dapat membantu penyembuhan luka adalah alkaloid, saponin, tanin dan flavanoid (Kaneria and Chandra, 2011; Ndukwe et al., 2013)

Analisis data dengan Uji Wilcoxon terhadap jumlah netrofil menunjukkan ada beda signifikan $(\mathrm{p}<0,05)$ antara kontrol dengan perlakuan daun jambu biji baik dengan pelarut air maupun pelarut alkohol. Hasil menunjukkan bermakna antara kontrol negatif dengan kontrol positif, kontrol negatif dengan ekstrak pelarut air, dan kontrol negatif dengan ekstrak pelarut alkohol.Netrofil merupakan jenis leukosit yang muncul pertama kali pada saat terjadi luka yaitu dengan cara berpindah ke daerah yang sedang mengalami serangan 
bakteri dengan cara menembus dinding

pembuluh dan menyerang bakteri untuk dihancurkan (Frandson, 1996), disaat yang sama flavanoid melakukan perannya untuk menghentikan pendarahan. Netrofil dalam menjalankan aktivitasnya bekerjasama dengan zat aktif karena netrofil memiliki fungsi yang hampir sama dengan tanin dan alkaloid yaitu menyerang mikroorganisme sehingga luka tetap steril, sehingga tidak terjadi infeksi (Jun$\mathrm{O}$ and Qing, 2014). Di samping itu, kandungan antioksidan yang terkandung dalam daun jambu biji mampu menghambat peningkatan netrofil (Fernandes et al., 2014).

Analisis data dengan UjiWilcoxon terhadapjumlah limfosit menunjukkan bahwa ada beda signifikan $(\mathrm{p}<0,05)$ antara kontrol dan perlakuan. Hasil menunjukkan bermakna antara kontrol negatif dengan kontrol positif, kontrol negatif dengan ekstrak pelarut air, kontrol negatif dengan pelarut alkohol.Hal ini disebabkan karena netrofil sebagai pertahanan pertama setelah melakukan fagositosis akan mengalami apoptosis (Jun-O and Qing, 2014), sehingga pada saat netrofil mengalami apoptosis, limfosit masih melakukan aktivitasnya. Hal tersebut menunjukkan bahwa saat jumlah netrofil kembali normal, jumlah limfosit masih berada di bawah batas normal, karena masih melakukan aktivitas penyembuhan luka yaitu fase proliferasi. Tahap penyembuhan pada fase proliferasi meupakan fase disintesisnya kolagen yang berfungsi untuk menkaitkan antara tepi luka, pada fase ini limfosit bekerja sama dengan saponin sehingga dihasilkan penyembuhan yang maksimal.

Ditemukannya hasil yang tidak signifikan antara kontrol positif dengan ekstrak yang diberi pelarut air maupun pelarut alkohol, begitu juga dengan ekstrak yang di beri pelarut air dengan ekstrak pelarut alkohol ditemukan hasil tidak signifikan dalam hal jumlah netrofil dan limfosit $(\mathrm{p}>0,05)$.

Hal ini disebabkan karena stres dapat mempengaruhi sistem kekebalan tubuh. Kannan et al. (2000) menyatakan bahwa penurunan sistem kekebalan tubuh akan memberikan efek samping berupa perubahan jumlah leukosit baik pada jumlah netrofil maupun jumlah limfosit. Suhu lingkungan, jumlah leukosit dapat meningkat pada saat suhu lingkungan rendah, sebaliknya jumlah leukosit dapat mengalami penurunan ketika suhu lingkungan tinggi (Wientarsih et al., 2013). Penurunan nafsu makan dapat 
mempengaruhi sistem hematopoiesis

(pembentukan sel darah) dan menunjukkan penurunan jumlah leukosit, trombosit dan retikulosit (Weiss and Wardrop, 2010). Faktorfaktor lain yang dapat mempengaruhi penyembuhan luka adalah infeksi, emosional dan trauma (Perry and Potter, 2000).

Berdasarkan hasil penelitian dapat disimpulkan bahwa ekstrak daun jambu biji baik dengan pelarut air maupun pelarut alkohol dapat digunakan sebagai obat luka dan memiliki efek penyembuhan luka dengan potensi yang sama dengan kontrol positif. Hal tersebut di sebabkan karena adanya kandungan zat aktif yang terdapat pada daun jambu biji (Ndukwe et al., 2013).

\section{SIMPULAN}

Ekstrak daun jambu biji (Psidium guajava Linn) mempercepat lama penyembuhan luka pada kulit, dibandingkan kontrol negatif.Uji terhadap jumlah netrofil maupun jumlah limfosit menunjukkan ada beda signifikan $(p<0,05)$ antara kontrol dengan perlakuan daun jambu biji baik dengan pelarut air maupun pelarut alkohol.

\section{DAFTAR PUSTAKA}

Aaron, A., Awaloei, H., dan Wuisan, J. 2016. Uji efek ekstrak daun dewa
(Gyanurasegetum [Lour]. Merr) terhadap masa penyembuhan luka insisi kulit kelinci (Oryctolaguscuniculus). Jurnal e-Biomedik (eBm), Volume 4, Nomor 1, Januari-Juni 2016.

Aliagaoglu, C., Turan, H., Uslu, E., Albayrak, H., Yazici, S., and Kaya, E. 2013. Iododerma following topical povidoneiodine application. Cutan Ocul Toxicol. 32(4): 339-40.

Carey, F. A. 2006. Organic Chemistry. 6 thed. New York: McGraw Hill, 954.

Fernandes, M.R.V., Azzolini, A.E.C.S., Martinez, M.L.L., Souza, C.R.F., Lucisano-Valim, Y.M., and Oliveira, W.P. 2014. Assessment of Antioxidant Activity of Spray Dried Extracts of Psidium guajava Leaves by DPPH and Chemiluminescence Inhibition in Human Neutrophils. BioMed Research International. Volume. 2014.

Frandson, R.D. 1996. Anatomi dan Fisiologi Ternak. Ed ke-4. B Srigandono, Koen P, penerjemah.Yogyakarta: Gadjah Mada University Press.Terjemahan dari : Anatomy and Physiology of Farm Animals.

Gray, P.E. Katelaris, C.H., and Lipson, D. 2013. Recurrent anaphylaxis caused by topical povidone-iodine (Betadine). J Paediatr Child Health. 49(1): 506-7.

Jun-O, J. and Qing, Y. 2014. Fucoidan Delays Apoptosis and Induces Pro-Inflammatory Cytokine Production in Human Neutrophils. International Journal of Biological Macromolecules. China. DOI: 10.1016/j.ijbiomac.2014.10.059.

Kaneria, M. and Chanda, S. 2011. Phytochemical and Pharmacognostic Evaluation of Leaves of Psidium guajava Linn. (Myrtaceae). Gujarat, India. Pharmacognosy Journal. Vol 3. DOI:10.5530/pj.2011.23.6.

Kannan, G., Terrill, T H., Kouakou, B., Gazal, O S.,Gelaye, S., Amoah, E A., and Samake, S. 2000. Transportation of Goats: Effects on Physiological Stress Responses and Live Weight Loss. J. of Animal Sci. 78:1450-1457.

Ndukwe, O K., Awomukwu, D., and Ukpabi, C F. 2013. Comparative Evaluation of Phytochemical and Mineral Constituents 
of the Leaves of some Medicinal Plants in Abia State Nigeria. International Journal of Academic Research in Progressive Education and Development. vol.2, No.3. DOI:10.6007/IJARPED/v2-i3/148.

Perry, A.G., and Potter, P.A. 2000. Perry Guide to Basic Skill and Prosedur Dasar, Edisi III, Alih bahasa Ester Monica. Jakarta, Penerbit Buku Kedokteran EGC.

Robinson, T. 1995. Kandungan Organik Tumbuhan Tinggi. Penerbit: ITB. Bandung.

Suratman, S A., Sumiwi, D., dan Gozali, G. 1996. Pengaruh Ekstrak Antanan dalam Bentuk Salep, Krim dan Jelly terhadap Penyembuhan Luka Bakar. Cermin Dunia Kedokteran 108:31-36.
Venkatachalam, N.R., Singh, K., and Marar, T. 2012. Phytochemical Screening and In Vitro Antioxidant Activity of Psidium guajava Linn. Free Radicals and Antioxidants journal Vol. 2 / Issue 1 / JanMar, 2012. India. DOI:10.5530/ax.2012.2.7.

Weiss, D.J., and Wardrop, K.J. 2010. Schalm's Veterinary Hematology 6 Edition. WilleyBlackwell, USA. Halaman 78-84, 152-161.

Widjajakusumah, M.D. 2002. Buku Ajar Fisiologi Kedokteran. Jakarta. EGC.

Wientarsih, I., Widhyari, S.D., dan Aryanti, T. 2013. Kombinasi Imbuhan Herbal Kunyit dan Zink dalam Pakan sebagai Alternatif Pengobatan Kolibasilosis pada Ayam Pedaging. Jurnal Veteriner, 14(3): 327334. 